\title{
LUNG FUNCTION STUDIES. IV. POSTURAL CHANGES IN RESPIRATORY DEAD SPACE AND FUNCTIONAL RESIDUAL CAPACITY ${ }^{1}$
}

\author{
BY WARD S. FOWLER 2 \\ (From the Department of Physiology and Pharmacology, Graduate School of Medicine, \\ University of Pennsylvania, Philadelphia)
}

(Received for publication May 24, 1950; accepted, July 24, 1950)

\begin{abstract}
Various observers have noted postural changes in certain lung volumes, such as vital capacity, expiratory reserve and functional residual capacity. Comparative studies of the respiratory dead space in different postures apparently have not been made although the volume of the dead space, as measured by various methods, has been found to vary with the extent of lung inflation. The effect of change in posture upon the respiratory dead space is of interest, since pulmonary efficiency is evaluated clinically using various types of "dead space" measurements in different postures (1-3). The studies reported here indicate that the volume of the respiratory dead space (the volume of inspired gas which does not contribute to dilution of alveolar gas) is greater when the subject is sitting than when supine; these postural changes are associated with similar changes in functional residual capacity.
\end{abstract}

\section{METHODS}

The subjects were five healthy male physicians, varying in age from 27 to 35 years. The "estimation" method of measuring respiratory dead space by the use of the Lilly nitrogen and flow meters (4) was used with one change: the calibration of the flow meter was obtained by passing expired gas through it to a recording spirometer so that the actual volume could be related to the area bounded by the flow record and its zero line. Details of the expiratory flow pattern cannot be recorded faithfully by this technique, but the flow tracings are satisfactory for the measurement of dead space.

Each subject assumed, in varying order, three positions : (1) sitting in a chair, (2) lying in bed with the head and trunk elevated $45-60^{\circ}$ above the bed, (3) supine in bed with one pillow under the head. After he had rested several minutes in a given position, the subject breathed $\mathrm{O}_{2}$ for at least one minute. Respiratory dead space was measured from the records of four successive expirations in each position. The mean values for each subject are given in Table I; a difference of $13 \mathrm{ml}$ or more between

1 This research was supported by a grant from the Commonwealth Fund.

2 National Institute of Health Postdoctorate Fellow. these means is significant. The average tidal volume for the first minute of $\mathrm{O}_{2}$ breathing was obtained from the spirometric record. All volumes are corrected to BTPS.

Changes in functional residual capacity were measured in the same subjects in the same three positions. Subjects rebreathed for an eight to ten minute period into a 6 liter recording Benedict-Roth type spirometer filled with $\mathrm{O}_{2}$ and containing a $\mathrm{CO}_{2}$ absorber. During this time they were placed in the various postures and maintained there until a fairly stable end-expiratory level was evident, usually within about ten breaths. Because a continuous spirometric record was necessary, these changes in position were made rapidly by using a chair with a hinged back. Best straight lines (slopes) were drawn on the record defining end-expiratory level for each position. Thus, if on changing from the sitting to the supine position, the volume of gas in the spirometer increased $800 \mathrm{ml}$, the volume of the functional residual capacity was considered to have decreased by a similar amount.

\section{RESULTS}

All subjects had smaller functional residual capacities in the semi-reclining and supine positions than when sitting. The average decreases were respectively 556 and $787 \mathrm{ml}$.

The respiratory dead space in all subjects was significantly smaller in the supine position than when sitting; the respective average values were 101 and $147 \mathrm{ml}$. The mean decrease, $46 \mathrm{ml}$, was highly significant $(p=0.01)$. In the semi-reclining position intermediate values, averaging 124 $\mathrm{ml}$, were found.

The dead space/tidal volume fraction was reduced from an average value of $27.5 \%$ in the sitting position to $18 \%$ in the supine position. The mean decrease, $9.5 \%$, was significant $(p=0.05)$.

\section{DISCUSSION}

Previous studies have shown that the volume of the respiratory dead space varies directly with changes in lung inflation produced voluntarily or by hyperventilation (4). These data indicate a 
WARD S. FOWLER

TABLE I

Respiratory measurements in various postures

\begin{tabular}{|c|c|c|c|c|c|c|c|c|c|c|c|c|c|c|c|}
\hline \multirow[b]{2}{*}{ Subject } & \multicolumn{5}{|c|}{ Sitting } & \multicolumn{5}{|c|}{ Semi-reclining } & \multicolumn{5}{|c|}{ Supine } \\
\hline & $\begin{array}{l}\text { Resp. } \\
\text { dead } \\
\text { space }\end{array}$ & $\begin{array}{c}\text { Tidal } \\
\text { vol. }\end{array}$ & $\frac{\mathrm{RDS}}{\mathrm{TV}} \times 100$ & $\begin{array}{l}\text { Insp. } \\
\text { time }\end{array}$ & $\begin{array}{c}\text { Min. } \\
\text { vol. }\end{array}$ & $\begin{array}{l}\text { Resp. } \\
\text { dead } \\
\text { space }\end{array}$ & $\begin{array}{l}\text { Tidal } \\
\text { vol. }\end{array}$ & $\frac{\text { RDS }}{\text { TV }} \times 100$ & $\begin{array}{l}\text { Insp. } \\
\text { time }\end{array}$ & $\begin{array}{c}\text { Min. } \\
\text { vol. }\end{array}$ & $\begin{array}{l}\text { Resp. } \\
\text { dead } \\
\text { space }\end{array}$ & $\begin{array}{l}\text { Tidal } \\
\text { vol. }\end{array}$ & $\frac{\mathrm{RDS}}{\mathrm{TV}} \times 100$ & $\begin{array}{l}\text { Insp. } \\
\text { time }\end{array}$ & $\begin{array}{c}\text { Min. } \\
\text { vol. }\end{array}$ \\
\hline $\begin{array}{l}\text { Ch. } \\
\text { Gf. } \\
\text { Hs. } \\
\text { Kg. } \\
\text { Md. }\end{array}$ & $\begin{array}{c}m l . \\
136 \\
201 \\
124 \\
171 \\
102\end{array}$ & $\begin{array}{c}m l . \\
565 \\
569 \\
447 \\
513 \\
600\end{array}$ & $\begin{array}{c}\% \\
24.1 \\
35.2 \\
27.7 \\
33.3 \\
17.0\end{array}$ & $\begin{array}{l}\text { sec. } \\
2.2 \\
1.4 \\
1.5 \\
1.9 \\
4.3\end{array}$ & $\begin{array}{l}\text { liters } \\
7.34 \\
7.40 \\
8.05 \\
8.72 \\
4.20\end{array}$ & $\begin{array}{c}m l . \\
123 \\
188 \\
103 \\
102 \\
105\end{array}$ & $\begin{array}{c}m l . \\
392 \\
650 \\
403 \\
559 \\
573\end{array}$ & $\begin{array}{c}\% \\
31.4 \\
29.0 \\
25.6 \\
18.3 \\
18.3\end{array}$ & $\begin{array}{l}\text { sec. } \\
1.8 \\
1.4 \\
1.9 \\
2.0 \\
2.7\end{array}$ & $\begin{array}{l}\text { liters } \\
6.28 \\
8.46 \\
7.25 \\
7.27 \\
5.16\end{array}$ & $\begin{array}{r}m l . \\
106 \\
144 \\
68 \\
108 \\
77\end{array}$ & $\begin{array}{c}m l . \\
436 \\
637 \\
463 \\
645 \\
673\end{array}$ & $\begin{array}{c}\% \\
24.3 \\
22.6 \\
14.7 \\
16.8 \\
11.4\end{array}$ & $\begin{array}{l}\text { sec. } \\
2.2 \\
1.4 \\
2.1 \\
1.9 \\
4.0\end{array}$ & $\begin{array}{l}\text { liters } \\
6.11 \\
8.29 \\
7.41 \\
9.70 \\
4.04\end{array}$ \\
\hline Mean & 147 & 539 & 27.5 & 2.3 & 7.14 & 124 & 515 & 24.5 & 2.0 & 6.88 & 101 & 571 & 18.0 & 2.3 & 7.11 \\
\hline
\end{tabular}

similar relationship when lung inflation varies with posture. Since no consistent or large changes of inspiratory time were observed (Table I) it does not appear likely that the changes in dead space can be attributed to changes in the extent of gaseous diffusion between terminal bronchioles and alveolar spaces.

As with other lung volumes, posture must be considered in the clinical use of measurements involving the volume of the respiratory dead space.

The postural changes in functional residual capacity observed here were similar to previous findings $(5,6)$.

\section{SUMMARY}

Postural changes in functional residual capacity and respiratory dead space were measured in five male subjects. The functional residual capacity, respiratory dead space, and the average dead space/tidal volume fraction were greater when
- the subjects were sitting than when supine. Intermediate values were obtained in the semi-reclining position.

\section{BIBLIOGRAPHY}

1. Birath, G., Lung volume and ventilation efficiency. Acta med. Scandinav., 1944, Supplement, 154.

2. Bateman, J. B., The measurement of intrapulmonary mixing and pulmonary midcapacity ("functional residual air"). Proc. Staff Meet., Mayo Clin., 1946, 21, 112.

3. Riley, R. L., and Cournand, A., "Ideal" alveolar air and the analysis of ventilation-perfusion relationships in the lungs. J. Applied Physiol., 1949, 1, 825.

4. Fowler, W. S., Lung function studies. II. The respiratory dead space. Am. J. Physiol., 1948, 154, 405.

5. Hurtado, A., and Fray, W. W., Studies of total pulmonary capacity and its subdivisions. III. Changes with body posture. J. Clin. Invest., 1933, 12, 825.

6. Livingstone, J. L., Variations in the volume of the chest with posture. Lancet, 1928, 1, 754. 